\title{
RUANG SAKRAL DAN PROFAN DALAM ARSITEKTUR MASJID AGUNG DEMAK, JAWA TENGAH
}

\author{
Dwindi Ramadhana ${ }^{1}$, Atyanto Dharoko ${ }^{2}$ \\ 1,2 Jurusan Teknik Arsitektur dan Perencanaan FT UGM \\ Email: dwindi@mail.ugm.ac.id
}

\begin{abstract}
Demak Great Mosque is a mosque of historical heritage during the Islamic kingdoms in the 14th century. Until now, this mosque still has an important share for the community as a place of religious worship and considered sacred. Against this background and the social conditions of society have developed, there is an indication that the Great Mosque of Demak has its own meaning on the spaces within the mosque-related to sacred and profane. The purpose of this research is to identify the sacred and profane space in the architecture of the Grand Mosque of Demak and identify the factors that influence the formation of the properties of the space. This research uses rationalistic approach and deductive qualitative method. The result of this study reveals that in its use, the spaces at the Great Mosque of Demak are divided into a room that is not worldly (sacred) and the room that is worldly (profane). Space that is (not worldly) is liwan and pawestren. While the worldly room is pawestren and porch. Factors affecting the sanctity of space are physical barriers and holiness of worship space. While sanctity becomes a legitimate requirement of worship activities, so it becomes the main requirement of the sacred or not a place.
\end{abstract}

Keywords: Demak, Mosque, Profane, Sacred

\begin{abstract}
ABSTRAK
Masjid Agung Demak adalah masjid warisan sejarah selama kerajaan Islam di abad ke-14. Hingga saat ini, masjid ini masih memiliki andil penting bagi masyarakat sebagai tempat ibadah dan dianggap sakral. Dengan latar belakang ini dan kondisi sosial masyarakat telah berkembang, ada indikasi bahwa Masjid Agung Demak memiliki maknanya sendiri di ruang-ruang di dalam masjid yang berkaitan dengan sakral dan profan. Tujuan dari Kajian ini adalah untuk mengidentifikasi ruang sakral dan profan dalam arsitektur Masjidil Haram dan mengidentifikasi faktor-faktor yang mempengaruhi terbentuknya sifat ruang. Kajian ini menggunakan pendekatan rasionalistik dan metode kualitatif deduktif. Hasil Kajian ini mengungkapkan bahwa dalam penggunaannya, ruang di Masjid Agung Demak terbagi menjadi ruangan yang tidak bersifat duniawi (sakral) dan ruangan yang bersifat duniawi (profan). Ruang yang (bukan duniawi) adalah liwan dan pawestren. Sedangkan ruang duniawi adalah pawestren dan serambi. Faktor-faktor yang mempengaruhi kesucian ruang adalah penghalang fisik dan kesucian ruang ibadah. Sedangkan kesucian menjadi kebutuhan ibadah yang sah, sehingga menjadi kebutuhan utama yang sakral atau bukan tempat.
\end{abstract}

Kata kunci: Demak, Masjid, Profane, Sakral

\section{PENDAHULUAN}

Masjid Agung Demak adalah peninggalan sejarah Islam yang sampai saat ini masih ada di kota Demak. Masjid Agung Demak diyakini sebagai pusaka bagi tanah Jawa dari masa awal kedatangan Islam, khususnya bagi kerajaan-kerajaan Islam yang mengikutinya. Purwanto (2014) mengatakan bahwa Masjid Agung Demak merupakan salah satu artefak peninggalan kebudayaan Kerajaan Demak yang masih lengkap dan utuh. Artefak ini selesai dibangun pada tahun 1403 Caka atau 1481 Masehi. Masjid ini berdiri di atas tanah seluas kurang lebih 1,5 hektar di kawasan pusat kota dan berfungsi sebagai masjid Jami', masjid negara kesultanan Demak pada zaman dahulu.

Purwanto (2014) berpendapat, sampai saat ini keberadaan citra Masjid Agung Demak masih tinggi terbukti suasana religius dan bangunan yang dianggap suci. Terlihat dari pengunjung yang datang berbondongbondong untuk beribadah dan berziarah ke makam-makam para sunan yang ada disekitar Masjid Agung Demak. Mereka yang datang ingin merasakan kesakralan suasana yang ada didalamnya dan mengharapkan pahala serta keberkahan hidup. 
Bangunan ibadah yang memiliki nilai kesakralan ditentukan dari nilai agama, latar budaya, simbolisasi dan tujuan spiritualnya, karena bangunan yang memiliki nilai-nilai sakral akan terpancarkan pada tempat yang terbangun untuk menghasilkan makna dari simbol dan akomodasi ritual pada sistem kepercayaan yang dianut oleh masyarakat setempat (Marwoto, et.all, 2014). Fenomena ruang pada Masjid Agung Demak memunculkan rasa keingintahuan dan ketertarikan mengenai bagaimana penggunaan ruang pada arsitektur Masjid Agung Demak yang telah terjadi dan apa faktor-faktor yang menyebabkan ruang sakral dan profan arsitektur bangunan masjid.

Schoggen dalam Sarwono (2002) berpendapat, pengertian setting diartikan sebagai tatanan suatu lingkungan yang dapat mempengaruhi perilaku manusia, artinya ditempat yang sama, perilaku manusia dapat berbeda jika setingnya (tatanannya) berbeda. Menurut Gobel (2012 dalam Malangjudo, 2015) setting dapat terbagi menjadi dua bagian, yaitu komponen bangunan dan properti. Properti adalah karakter atau kualitas dari komponen. Sedangkan komponen terdiri atas tiga kategori, yaitu komponen fixed, komponen semi fixed dan komponen non fixed. Rapoport (1991) dalam Setiawan (2005), mengungkapkan bahwa ruang yang menjadi wadah dari aktivitas diupayakan untuk memenuhi kemungkinan kebutuhan yang diperlukan manusia, yang artinya menyediakan ruang yang memberikan kepuasan bagi pemakainya. Setting terkait langsung dengan aktivitas manusia sehingga dengan mengidentifikasi sistem aktivitas atau perilaku yang terjadi dalam suatu ruang ajan teridentifikasi pula sistem settingnya yang terkait dengan keberadaan elemen dalam ruang.

Dhavamony (1995: 87) mengungkapkan bahwa yang sakral (kudus) adalah sesuatu yang terlindung dari pelanggaran, pengacauan dan pencemaran. Yang sakral adalah sesuatu yang dihormati, dimuliakan, dan tidak dapat dinodai. Dalam hal ini pengertian tentang yang kudus tidak hanya terbatas pada agama, maka banyak objek, baik yang bersifat keagamaan maupun bukan, tindakan-tindakan, tempat-tempat, kebiasaan-kebiasaan dan gagasan- gagasan dapat dianggap sebagai kudus. Sedangkan profan adalah sesuatu yang biasa, umum, tidak dikuduskan, dan bersifat sementara. Sementara itu, Ustadz Abu Ayub mengungkapkan bahwa mengingat salah satu makna sakral adalah keramat, terutama bagi masyarakat Jawa, Islam lebih mengenal istilah suci atau berkah. Suci adalah sesuatu yang terpisah dari sikap orang yang ingin menghormati yang dilakukan karena ada manfaat terhadap kehidupan sehari-hari. Jadi sebenarnya anggapan itu hanya terletak pada pemeluknya saja yang menyebabkan timbulnya perbedaan pandangan. Tentang wujud yang gaib disucikan, oleh karena mereka tidak dapat melihatnya, maka realitasnya tidak dapat ditunjukkan, yang bagi orang lain adalah suatu yang tidak ada. Namun bagi penganutnya, penghormatan itu benar-benar merupakan suatu yang suci, yang memungkinkan wujud yang disucikan itu terdapat di dalam diri para pemeluknya. Lebih jauh dari pada itu, wujud suci itu merupakan wujud yang dapat diselidiki secara empiris (Muhammad 2013). Sedangkan tempat suci adalah tempat keilahian kekudusan, berbeda dari tempat profan, karena inilah tempat tinggal yang ilahi. Tingkah laku di tempat yang seperti ini diperhatikan menyangkut kemurnian dan hormatnya yang khusus, tidak seperti di tempat profan (Muhammad, 2013).

Secara bahasa, kata masjid (مَنَ) adalah tempat yang dipakai untuk bersujud. Kemudian maknanya meluas menjadi bangunan khusus yang dijadikan orangorang untuk tempat berkumpul menunaikan shalat berjama'ah. Hal tersebut juga diperkuat dengan pernyataan Sumalyo (2006) mengungkapkan bahwa pada hakekatnya, masjid adalah tempat untuk melakukan segala aktivitas berkaitan dengan kepatuhan kepada Allah semata. Oleh karena itu, masjid dapat diartikan lebih jauh, bukan hanya sekedar tempat bersujud, pensucian, tempat shalat dan bertayamum, namun juga sebagai tempat melaksanakan segala aktivitas kaum muslim berkaitan dengan kepatuhan kepada Tuhan.

Fungsi masjid secara umum adalah untuk tempat umat Islam beribadah kepada Allah SWT. Ayub dkk (1996:7) mengatakan 
bahwa selain untuk bersujud, masjid juga digunakan untuk : a) tempat kaum muslimin beribadat dan mendekatkan diri kepada Allah SWT, b) tempat kaum muslimin beri'tikaf, membersihkan diri, menggembleng batin untuk membina kesadaran dan mendapatkan pengalaman batin/ keagamaan sehingga selalu terpelihara keseimbangan jiwa dan raga serta keutuhan kepribadian, c) tempat musyawarah kaum muslimin guna memecahkan persoalan-persoalan yang timbul dalam masyarakat, d) tempat kaum muslimin berkonsultasi, mengajukan kesulitan-kesulitan, meminta bantuan dan pertolongan.

\section{METODE}

Kajian ini menggunakan Kajian rasionalistik dengan metode deduktif kualitatif. Kajian ini menggunakan teori setting ruang sebagai teori yang mendasari terbentuknya ruang sakral dan profan di bangunan Masjid Agung Demak. Selain bertujuan untuk menemukan ruang sakral dan profan, Kajian ini juga bertujuan untuk menemukan faktor yang mempengaruhi terbentuknya ruang sakraldan profan tersebut.

Lokasi Kajian yaitu Masjid Agung Demak yang terletak di sebelah barat alun-alun kota Demak, Desa Kauman, Kecamatan Demak, Kabupaten Demak Provinsi Jawa Tengah.

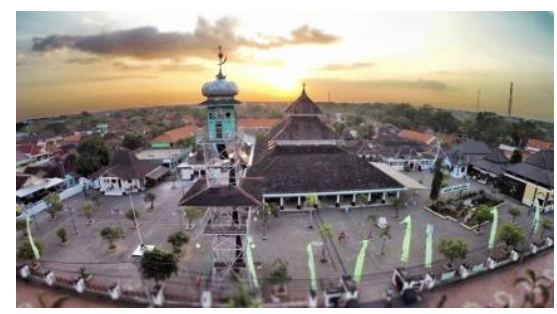

Gambar 1. Masjid Agung Demak pada saat ini (sumber: http://www.idsejarah.net (diakses 30 November 2017)
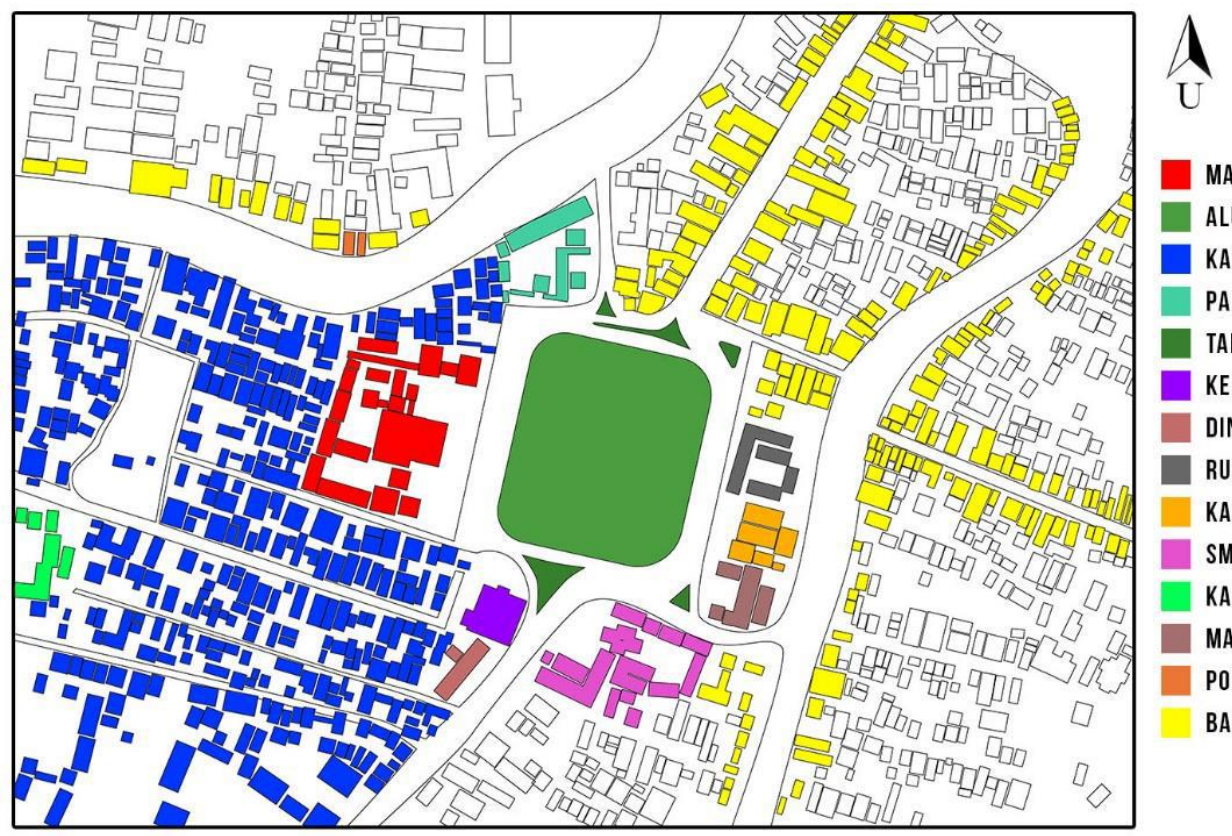

Gambar 1. Lokasi Masjid Agung Demak (sumber: analisis penulis, 2017)

Teknik pengumpulan data yang digunakan adalah observasi (dilakukan dengan melakukan dokumentasi, pengukuran dan pengamtan). Observasi di sini adalah pengamatan terhadap aktifitas pengunjung, observasi penggunaan ruang-ruang untuk mengidentifikasi ruangruang yang dianggap suci untuk beribadah dan ruang yang nyaman untuk bersantai. Observasi dilakukan untuk mendapatkan data per hari dari Senin sampai Ahad pada setiap jeda waktu shalat. Cara mencari dat ayang kedua adalah dengan literatur. Studi literatur dilakukan pada tinjauan pustaka, teori-teori dan konsep yang berkaitan dengan Kajian ini, studi literatur ini 
dilakukan sebgai bacground knowledge dalam Kajian ini. Literatur yang digunakan antara lain buku, jurnal, foto, sketsa, sumber internet, dan e-book.

Selanjutnya melakukan penyebaran kuesioner, daftar pertanyaan yang dibuat secara terstruktur dengan bentuk pertanyaan terbuka (open question). Metode ini digunakan untuk memperoleh data tentang aktifitas yang dilakukan oleh pengunjung selama berada di masjid, ruang-ruang mana saja yang dipergunakan dan persepsi pengunjung mengenai sakral dan profan ruang di Masjid Agung Demak. Dan cara terakhir adalah dengan melakukan wawancara yang dilakukan kepada takmir masjid untuk mengetahui data mengenai sejarah bentukan fisik bangunan masjid dan penggunaan ruang-ruang di dalam masjid pada masa itu, aktifitas keseharian dari pengunjung masjid, penggunaan ruangruang di masjid pada hari biasa maupun hari-hari besar.

Metode analisis yang dilakukan dalam Kajian ini dilakukan dalam beberapa langkah, di antaranya sebagai berikut: 1) Menggali secara luas tentang perkembangan arsitektur pada masjid di bangunan Masjid Agung Demak berdasarkan obyek Kajian yang ditetapkan, 2) Mengelompokkan hasil pengamatan pengunjung berdasarkan kegiatan yang dilakukan di Majid Agung Demak, kemudian membuat alur kegiatan pengunjung secara spesifik, 3) Mengolah (menganalisis) data kegiatan pengunjung dengan perhitungan teori sakral dan profan yang dijadikan dasar untuk mengetahui dominasi kegiatan pengunjung masjid 4) Mengolah (menganalisis) data kegiatan pengunjung berdasarkan persepsi responden dari hasil kuesioner, 5) Membahas hasil temuan antara hasil pengamatan dan hasil persepsi penggunaan ruang oleh pengunjung dengan teori perkembangan sakral dan profan. Dalam tahapan ini mencari hubungan konsep-konsep yang diperoleh dari konsep kesakralan ruang,sehingga diperoleh deskripsi analisis dan perbandingan kerangka konseptual menjadi hasil temuan mengenai konsep sakral profan bangunan Masjid Agung Demak.

\section{HASIL DAN PEMBAHASAN}

Identifikasi ruang sakral dan profan terbagi menjadi tiga bagian, yaitu berdasarkan alur kegiatan pengunjung, berdasarkan jenis kegiatan yang dilakukan di Masjid Agung Demak dan berdasarkan hasil kuesioner. Identifikasi ruang berdasarkan kegiatan pengunjung Masjid Agung Demak menghasilkan ruang-ruang yang dipergunakan oleh pengunjung untuk melakukan aktifitasnya di masjid.

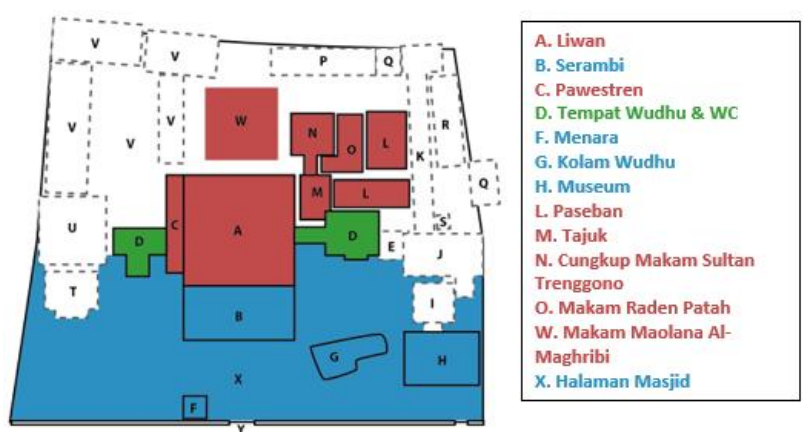

Gambar 3. Pemetaan berdasarkan Alur Kegiatan (sumber: analisis penulis, 2017)

Ruang yang masuk kategori sakral adalah Liwan, Pawestren, Paseban, Tajuk, Cungkup Makam Sultan Trengono, Makam Raden Patah dan Makam Maolana AlMaghribi, karena ruangan ini menjadi tujuan utama para jama'ah Shalat maupun peziarah datang ke Masjid Agung Demak. Liwan dan pawestren merupakan ruang ibadah yang terletak di dalam bangunan masjid. Makna sakral yang dimaksudkan untuk masjid adalah suci, karena masjid merupakan rumah Allah dan banyak keberkahan yang disebutkan dalam AlQur'an dan Hadits yang berkaitan dengan masjid. Serambi, sebagai ruang yang masih menyatu dengan masjid, memiliki status suci yang sama dengan liwan dan pawestren. Namun, berdasarkan hasil pengamatan alur kegiatan, serambi di Masjid Agung Demak digunakan sebagai tempat singgah dan tempat lewat oleh para jamaah, tanpa bersuci (wudhu) terlebih dahulu, sehingga serambi di Masjid Agung Demak masuk dalam kategori profan. Sedangkan Museum dan Halaman Masjid yang melingkupi Menara dan Kolam Wudhu juga masuk kategori profan karena para jamaah dan peziarah 
tidak perlu bersuci untuk memasukinya dan tidak ada kegiatan ritual khusus yang dilakukan di ruangan-ruangan ini.

Identifikasi ruang sakral dan profan berdasarkan analisis jenis kegiatan menghasilkan grafik sebagai berikut:

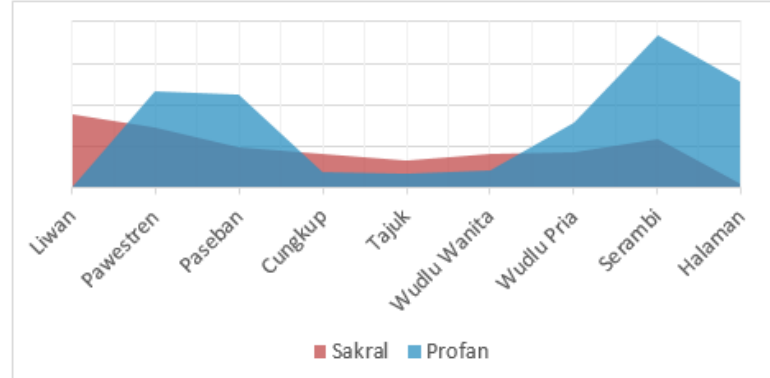

Gambar 4. Grafik Penggunaan Ruang (sumber: analisis penulis, 2017)

Dari tabel dan grafik di atas, maka dapat dipetakan ruang sakral dan ruang profan di Masjid Agung Demak berdasarkan pengamatan jenis kegiatan yang dilakukan oleh para pengguna ruang.

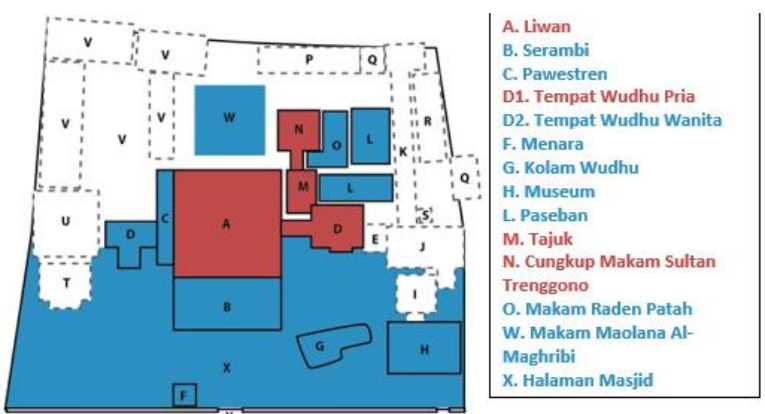

Gambar 5. Pemetaan berdasarkan Jenis Kegiatan (sumber: analisis penulis, 2017)

Pemetaan tersebut menunjukkan bahwa Liwan, Tempat Wudhu Pria, Tajuk dan Cungkup Makam Sultan Trenggono masuk dalam kategori sakral karena jenis kegiatan sakral yang mendominasi ruangruang tersebut. Liwan didominasi dengan kegiatan shalat, tilawah (membaca AlQur'an) dan i'tikaf, sehingga makna sakralnya adalah suci. Tempat wudhu pria, sebagai tempat bersuci dan melakukan kegiatan bersuci, maka tempat ini sakral dengan makna suci. Tajuk dan Cungkup Makam Sultan Trenggono sebagai tempat ziarah dan tak jarang peziarah yang tidak menghentikan kegiatannya ketika masuk waktu shalat, memprioritaskan kegiatan ziarah di atas shalat, dan tidak ada dalil yang membolehkan hal ini dilakukan maka makna sakral untuk kedua ruang ini adalah keramat. Sedangkan ruang-ruang lainnya masuk dalam kategori profan karena kegiatan profan yang mendominasinya.

Hasil identifikasi ruang sakral dan profan berdasarkan hasil kuesioner menghasilkan Liwan dan pawestren dianggap sakral lebih dari dua puluh orang, maka keduanya layak dimasukkan dalam kategori sakral. Tempat wudhu, paseban, tajuk, cungkup makam Sultan Trenggono, serta makam-makam memiliki lebih dari sepuluh dan kurang dari atau sama dengan dua puluh orang, maka dimasukkan dalam kategori transisi atau semi sakral. Serambi, museum dan halaman masjid yang melingkupi menara dan kolam wudhu dianggap sakral oleh kurang dari atau sama dengan sepuluh orang, maka ruang-ruang ini masuk dalam kategori profan.

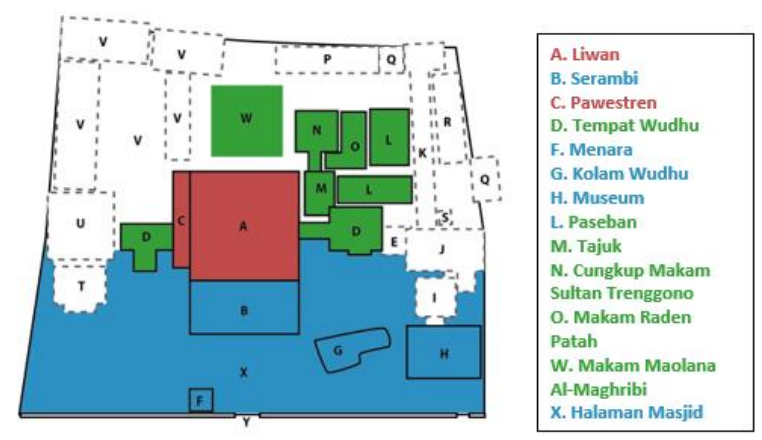

Gambar 6. Pemetaan berdasarkan Kuesioner (sumber: analisis penulis, 2017)

Secara normatif, ruang sakral digunakan untuk kegiatan sakral. Sebagaimana yang disebut oleh Dhavamony (1995:100) bahwa yang kudus (suci atau sakral) terdapat rasa takut dan hormat, hening dan menggetarkan jiwa serta penggunaan kata-kata suci. Dengan adanya penghormatan yang agung terhadap masjid sebagai Baitullah (rumah Allah), maka ruang-ruang sakral (suci) selayaknya digunakan untuk kegiatankegiatan suci seperti ibadah utama (Shalat, I'tikaf, tilawah, dll). Begitu juga dengan ruang yang terletak di luar bangunan masjid, ruang sakral (keramat) seperti makam wali yang dihormati seharusnya diisi dengan kegiatan-kegiatan yang sakral pula. Baik kegiatan suci atau keramat, namun ada batasan-batasan yang menunjukkan adanya penghormatan yang mengagungkan keduanya. Dari tiga 
puluh responden, 27 di antaranya tidak setuju bila ada kegiatan profan di ruang yang sakral.

Ruang transisi memiliki kedua jenis yaitu sakral dan juga profan. Ruang transisi merupakan ruang yang kebersihan dan kesuciannya juga diperhatikan oleh para pengurus masjid dan memenuhi syarat untuk digunakan sebagai tempat ibadah utama (kegiatan suci) dan juga ritual-ritual lain yang menurut kepercayaan pelakunya. Ruang transisi diperbolehkan pula digunakan untuk kegiatan yang profan, dengan syarat tidak mengganggu kegiatan sakral yang sedang berlangsung. Maka tidak ada masalah bila terdapat kegiatan baik sakral maupun profan di ruang transisi.

Ruang profan, sebagaimana Dhavamony (1995:87) mendefinisikannya sebagai sesuatu yang biasa, umum dan tidak dikuduskan, maka kegiatan-kegiatan yang terdapat dalam ruang-ruang profan adalah kegiatan-kegiatan biasa yang tidak ada kaitannya dengan riutual keagamaan atau ibadah.Ruang profan di Masjid Agung Demak sering menjadi perluasan ruang sakral (baik suci maupun keramat) ketika ruang sakral tidak mampu mewadahi jama'ah dalam acara atau kegiatan keagamaan tertentu. 26 dari 30 responden setuju bila kegiatan sakral dilakukan di ruang profan, dengan syarat menyucikan atau membersihkan ruang tersebut untuk kelayakan yang sesuai dengan syari'at atau syarat sah suatu ibadah. Seperti contoh kegiatan shalat, bila jama'ah harus ekspansi ke ruang profan karena ruang sakral (suci_telah penuh, maka upaya yang dapat dilakukan adalah memastikan lantai di ruang profan telah bersih atau menggelar alas berupa koran, tikar atau sajadah.

Data yang telah diperoleh yaitu pemetaan ruang sakral dan ruang profan yang dibuat berdasarkan tiga sumber data. Untuk mendeteksi adanya atau tidaknya kontradiksi antara jenis kegiatan dan kesucian/ kekeramatan ruang, maka data pemetaan ruang tersebut dikomunikasikan dengan cara layering.

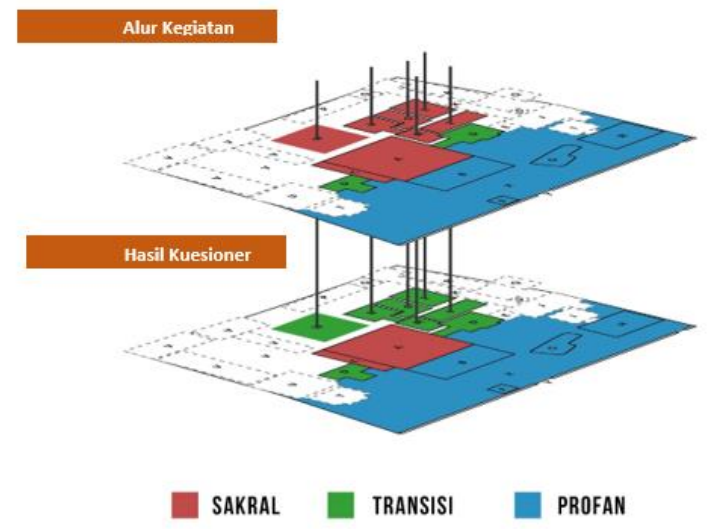

Gambar 7. Layering pemetaan Alur Kegiatan dengan Kuesioner

(Sumber: Analisis penulis)

Dari hasil layering antara pemetaan alur kegiatan dan hasil kuesioner, ditemukan perbedaan warna di beberapa ruang, yaitu makam-makam, paseban, tajuk dan cungkup. Perbedaan warna tersebut menunjukkan bahwa kegiatanyang terdapat pada ruang-ruang tersebut adalah kegiatan sakral yang dilakukan di ruang-ruang yang dianggap semi sakral (transisi). Sedangkan ruagn transisi lain, yaitu tempat wudhu, digunakan untuk kegiatan peralihan (transisi/semi sakral) dari tidak suci menjadi suci. Liwan dan pawestren sebagai ruang yang dianggap sakral (suci) juga terlihat digunakan untuk kegiatan yang sakral (suci) sebagai ruang yang menjadi tujuan utama para jama'ah Shalat. Sedangkan ruang-ruang profan, yaitu serambi, museum, dan halaman yang melingkupi menara dan kolam wudhu tidak terdapat konflik dengan alur kegiatan.

Berdasarkan definisi yang telah dipaparkan, ruang transisi layak digunakan sebagai tempat berkegiatan sakral (baik suci maupun keramat), karena kebersihan dan kesucian di ruang transisi juga mendapat perhatian khusus dari para pengurus masjid. Oleh karena itu, maka secara keseluruhan tidak ditemukan kontradiktif ruang antara pemetaan alur kegiatan dan pemetaan hasil kuesioner. 


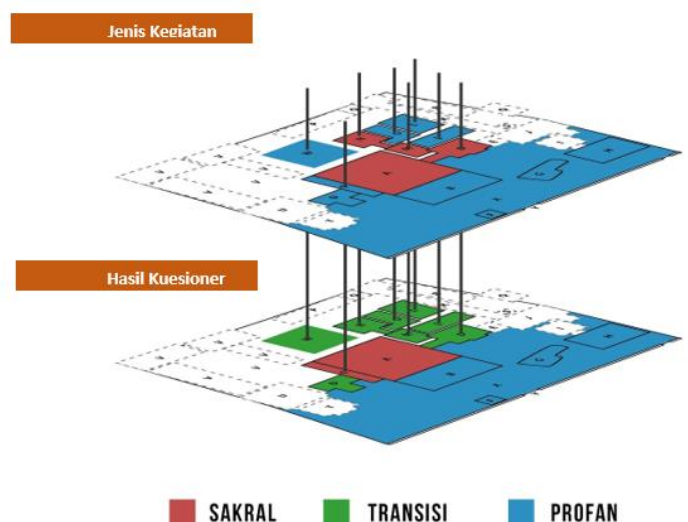

Gambar 8. Layering Pemetaan Jenis Kegiatan dengan Kuesioner

(Sumber: Analisis penulis)

Layering antara hasil pengamatan jenis kegiatan dan hasil dari kuesioner menunjukkan banyak konflik. Tempat wudhu wanita, paseban dan makammakam yang dianggap sebagai ruang semi sakral (transisi) didominasi oleh kegiatan profane, namun tempat wudhu pria, tajuk, dan cungkup yang juga dianggap sebagai ruang semi sakral (transisi) didominasi oleh kegiatan sakral. Dengan pembahasan pada layering sebelumnya, hal ini tidak menjadikan keduanya sebagai konflik ruang. Liwan yang dianggap sebagai ruang sakral (suci) didominasi oleh kegiatan sakral (suci), sebagaimana kondisi yang seharusnya terjadi sesuai syari'at dan definisi kudus/sakral dari Dhavamony (1995). Ruang pawestren yang juga dianggap sebagai ruang sakral (suci), menunjukkan adanya kontradiktif.

Berdasarkan hasil pengamatan dan jenis kegiatan, ruang yang dianggap sakral (suci) ini didominasi oleh kegiatan profane. Maka pawestren butuh analisis dan pembahasan yang lebih detail. Sedangkan ruang-ruang profane yang terdiri dari serambi, museum dan halaman masjid termasuk menara dan kolam wudhu tidak ditemukan adanya kontradiksi karena ruang-ruang profan ini didominasi oleh kegiatan profan.

Bangunan Masjid Agung Demak terdiri dari tiga ruang utama, yaitu Liwan, Pawestren, dan Serambi yang kemudian akan dibahas tentang kesakralan (kesucian) ruangnya lebih detail.

Liwan merupakan ruang paling utama dalam sebuah masjid. Ruang tersebut dijelaskan oleh Rasdi (1998) sebagai area suci, yang melarang wanita haid dan muslim yang junub/kotor untuk datang, masuk dan tinggal untuk beberapa saat. Area ini ditandai dengan penggunaan ruang untuk ber-tahiyyah (Shalat) dan l'tikaf.

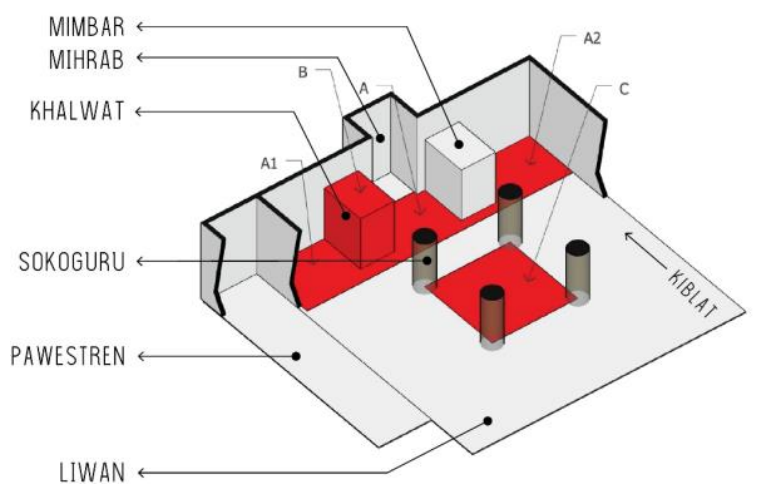

Gambar 9. Liwan

(Sumber: Analisis penulis)

Terutama di masjid tipe Jami', liwan terdiri dari mihrab (pengimaman), shaf-shaf shalat berupa sajadah panjang atau garisgaris penanda, dan juga mimbar untuk khatib mengisi cerama. Rasdi (1998) menyatakan bahwa ruang ini dapat digunakan untuk berbagai aktivitas apa pun oleh jama'ah, kecuali kegiatankegiatan yang bersifat pencemaran.

Liwan di Masjid Agung Demak memiliki beberapa titik yang diyakini lebih berkah, yaitu di shaf-shaf terdepan dengan alasan syari'at yang memang menyebutkan ada keberkahan yang lebih bila Shalat berjama'ah dan menempatkan diri di shaf terdepan.

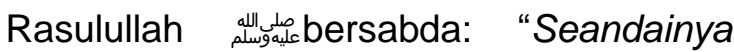
manusia mengetahui pahala yang terdapat dalam panggilan adzan dan shaf pertama, kemudian mereka tidak mendapatkan kecuali dengan diundi, niscaya mereka melakukannya." (HR. Bukhari dari Abu Hurairah radiyallahu 'anhu) Yakin dengan adanya keberkahan atau keutamaan di shaf terdepan ketika Shalat, hal ini diterapkan oleh orang-orang yang beri'tikaf, yaitu berdiam diri di masjid dengan melakukan Shalat malam, dzikir 
atau pun membaca Al-Qur'an. Secara umum, shaf terdepan (A) memiliki kesakralan yang lebih tinggi. Gus Faturrahman menjelaskan adanya keistimewaan yang spesifik di bagian selatan dan bagian utara shaf terdepan dalam liwan. Bagian selatan (A1) digunakan bila akan berdoa meminta hal yang berkaitan dengan keduaan seperti kelulusan, kesuksesan, jabatan dan sejenisnya. Sedangkan bagian utara (A2) digunakan bila akan berdoa untuk meminta hal yang berkaitan dengan ghaib, seperti meminta ampunan dosa dan sejenisnya.

Kamar khalwat (B), yaitu ruangan kecil yang memutus shaf pertama hingga shaf ketiga yang konon digunakan sebagai tempat ber-khalwat para wali dan digunakan sebagai tempat Shalat pangeran, kini digunakan sebagai ruang persiapan bagi imam sebelum memimpin Shalat. Tidak ada ayat maupun Hadits yang menerangkan tentang hal tersebut, maka makna sakralnya adalah keramat.

I'tikaf di antara empat saka guru (c) juga diyakini dapat memberikan banyak kemuliaan dan keutamaan amalan. Konon, menurut cerita Gus Faturrahman, area di antara saka guru ini digunakan oleh para wali untuk berdiskusi tentang strategi dakwah dan beribadah. Soko guru merupakan emen khas bangunan Jawa. Tidak ada dalil Al-Qur'an dan Hadits yang membahasnya, maka kesakralan yang disebut bermakna keramat.

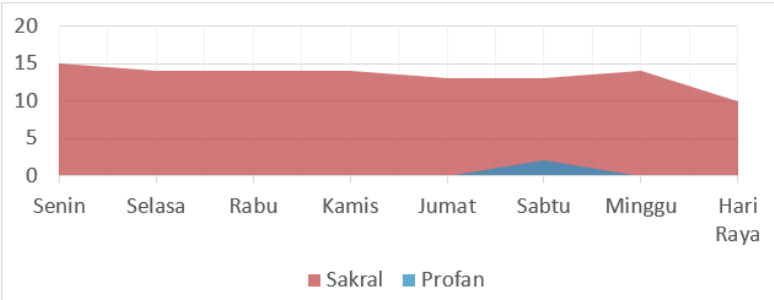

Gambar 10. Grafik Kegiatan Sakral Profan di Liwan

(Sumber: Analisis Penulis)

Dilihat dari grafiknya, setiap hari liwan selalu didominasi secara signifikan oleh kegiatan sakral (suci), yaitu Shalat, I'tikaf dan tilawah. Namun ada sedikit kegiatan profan (warna biru) yaitu kegiatan menerima tamu dan berfoto. Kegiatan ini terjadi ketika Masjid Agung Demak dikunjungi oleh Imam Besar dari Turki, yaitu Mawlana Syaikh Muhammad Adil ArRabbani. Beliau disambut pengurus di Liwan.

Ustadz Abdullah Imam ketika membicarakan "kesalahan-kesalahan ketika di masjid" menyatakan: “...Pada dasarnya tidak mengapa berbicara atau berbincang tentang urusan dunia di masjid dengan syarat pembicaraannya ringan, tidak meluas, tidak rebut dan tidak mengganggu orang lain yang sedang beribadah di masjid tersebut. Jika tidak terpenuhi syarat-syarat tersebut maka hukumnya makruh..."

Maka, bukan suatu pelanggaran bila berkumpul dan membicarakan tentang kepentingan dunia selama hal tersebut tidak berlarut-larut, sehingga tidak mengusik kesakralan, baik suci maupun keramat.

Pawestren merupakan ruagn yang disediakan khusus untuk wanita, sehingga tidak ada pria yang diperkenankan masuk atau bergabung dalam ruang ini sekalipun ia bertindak sebagai imam atau memimpin Shalat berjama'ah. Pawestren menjadi tempat yang paling aman untuk wanita membuka hijabnya demi berbagai kepentingan. Hal ini terbentuk karena aturan syari'at yang mewajibkan wanita untuk menutup seluruh tubuhnya kecuali wajah dan telapak tangan, dan hal ini diketahui oleh setiap Muslim (pria) dan Muslimah (wanita) di seluruh penjuru dunia, sehingga sikap menjaga diri dengan menutup baik dengan pakaian yang tertutup maupun beraktivitas di ruangan tertutup dari pandangan pria adalah suatu sikap ketaatan terhadap perintah Allah.

Ruang khusus wanita ini dianggap sebagai ruang sakral karena fungsinya yang terbatas hanya untuk wanita dan untuk melaksanakan ibadah. Maka makna sakral di ruang pawestren ini adalah suci, $\mathrm{Hal}$ ini dapat dilihat ketika waktu Shalat, pawestren dipenuhi oleh jama'ah wanita yang melaksanakan Shalat. Namun, ketika pelaksanaan Shalat usai, hasil pengamanan jenis kegiatan menunjukkan banyaknya kegiatan profan di ruang 
pawestren ini, sehingga jenis kegiatan yang mendominasi ruang pawestren adalah kegiatan profan secara signifikan.

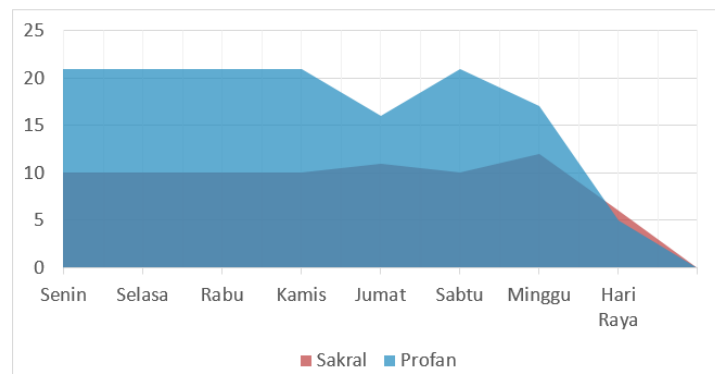

Gambar 11. Grafik Kegiatan Sakral Profan di Pawestren

(Sumber: Analisis Penulis)

Berdasarkan grafik, sangat jelas kegiatan yang mendominasi adalah kegiatan profan. Untuk dapat lebih mengidentifikasi konflik yang terjadi di ruang pawestren ini, maka pengamatan dilakukan lebih detail.

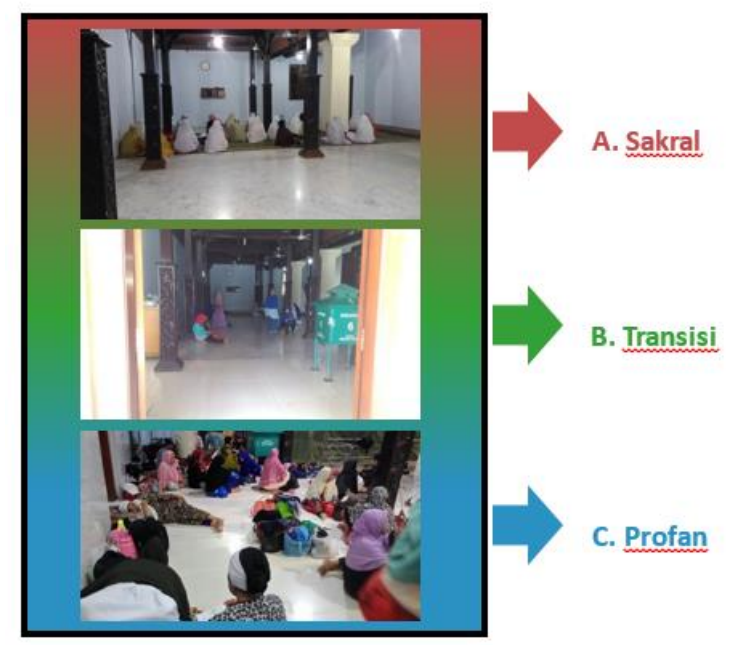

Gambar 12. Pola Kegiatan di Pawestren

(Sumber: Analisis Penulis)

Pawestren didominasi oleh kegiatan sakral hanya ketika masuk waktu Shalat saja. Setelah rentang waktu pelaksanaan Shalat tersebut, kegiatan mulai beragam. Di area paling barat atau paling mendekati kiblat (A) tetap digunakan untuk beribadah Shalat bagi jama'ah yang datang terlambat. Bagian tengah (B) mulai terlihat wanita-wanita yang duduk-duduk santai dan bicara dengan suara pelan, cenderung berbisik. Sedangkan bagian paling timur atau paling jauh dari kiblat (C) digunakan untuk berbagai kegiatan seperti berbaring, berdandan, berfoto, bercengkrama dan lainnya.
Serambi, sebagia bagian dari masjid, merupakan ruang suci multifungsi. Serambi Masjid Agung Demak mengakomodasi hampir seluruh kegiatan masjid. Secara kasat mata, ruang serambi digunakan untuk singgah dan berlalulalang walaupun tidak dalam keadaan suci, karena serambi banyak dilewati oleh jama'ah atau peziarah yang belum bersuci kemudian melewati serambi menuju tempat wudhu baik wanita maupun pria.

Keadaan tidak suci (berhadas kecil), bahkan haid atau junub (berhadas besar) diperbolehkan melewati masjid secara umum. Namun Masjid Agung Demak hanya membiarkan bagian serambi yang menjadi tempat lalu-lalang jama'ah, sedangkan liwan dan pawestren dijaga dari jama'ah yang masih dalam keadaan belum suci (berhadas).

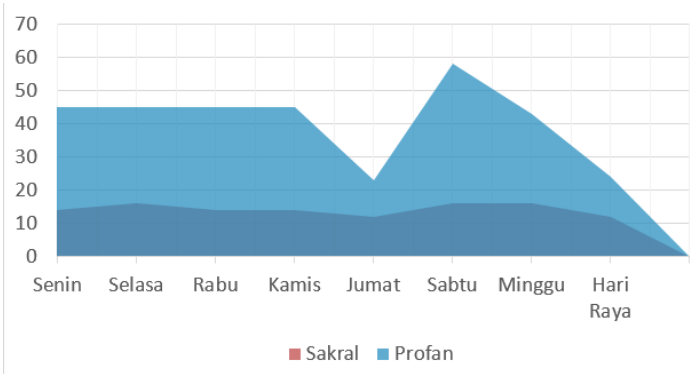

Gambar 13. Grafik Kegiatan di Serambi (Sumber: Analisis Penulis)

Serambi digunakan sebagai ruang Shalat bagi para peziarah yang datang setelah jam Shalat dan tertinggal oleh jama'ah kloter pertama yang diimami oleh imam pilihan takmir. Seringnya peziarah melaksanakan Shalat berjama'ah bersama rombongannya baik pria maupun wanita dan dilaksanakan di serambi. Shalat juga dilaksanakan oleh pengunjung yang datang setelah jam 8 malam, karena liwan ditutup dari jam 8 hingga jam 12 malam dengan alasan keamanan, kebersihan dan perawatan. Kecenderungan tempat yang dipilih adalah bagian tengah serambi. 


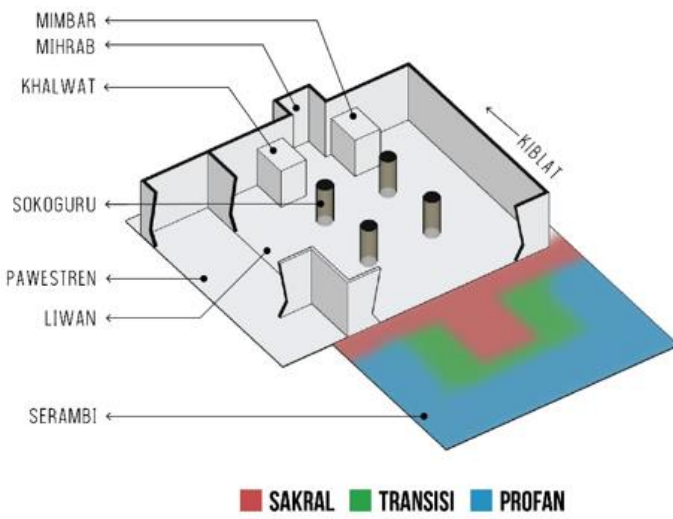

Gambar 14. Pola Kegiatan Sakral Profan di Serambi

(Sumber: Analisis Penulis)

Kegiatan suci lainnya yang dilaksanakan di serambi yaitu membaca Al-Qur'an yang dipimpin oleh seorang Hafidz (penghapal Al-Qur'an) setiap hari antara waktu maghrib dan isya. Hafidz dan jama'ah pria duduk di tengah serambi, sedangkan jama'ah wanita duduk di shaf depan serambi di bagian selatan (mendekati pawestren) dengan ditutupi kain hijab (pembatas).

Selain itu, bagian tengah serambi juga dipilih sebagai tempat melaksanakan akad nikah. Pernikahan adalah kegiatan sakral (suci), namun tidak dilaksanakan di lliwan sebagai ruang paling sakral (suci) dengan alasan menjaga kesucian. Dikhawatirkan ada peserta acara pernikahan baik keluarga maupun kerabat mempelai yang sedang haid ketika menghadiri acara. Serambi juga diperbolehkan untuk pemasangan segala perlengkapan dokumentasi untuk mengabadikan momen pernikahan.

Kegiatan profan mulai terlihat di bagian tengah selatan dan utara yang dipilih oleh pengguna ruang untuk duduk-duduk santai atau sekadar bercengkrama dengan suara yang tidak keras. Menjaga suara dilakukan agar tidak mengganggu konsentrasi atau kekhusu'an para jama'ah yang Shalat di dekatnya. Di bagian ini pula pengguna ruang juga merasa nyaman untuk mengeluarkan bekal berupa makanan atau minuman yang mereka bawa sendiri.
Bagian pinggir serambi, baik sisi selatan, timur maupun utara digunakan untuk kegiatan profane. Di bagian ini pengguna ruang merasa sangat nyaman untuk beristirahat, berbaring, berfoto bahkan para pedagang tidak sungkan untuk menjajakan barang dagangannya kepada pengguna ruang yang sedang duduk santai di pinggiran serambi ini. Pinggiran serambi di sisi utara adalah bagian favorit bagi para jama'ah pria untuk merokok.

Secara menyeluruh, serambi digunakan untuk berbaring bahkan tidur, baik oleh pria maupun wanita, pada malam hari sambil menunggu waktu Shubuh datang.

Pembatas ruang memiliki peran besar dalam membentuk persepsi pengguna ruang dalam menggunakan ruang yang sedang dimasukinya. Bangunan Masjid Agung Demak memiliki keunikan fungsi pembatas ruang yang menarik untuk dibahas. Dengan pembatas yang serupa, fungsi pembatas ruang di liwan dan pawestren memiliki perbedaan yang

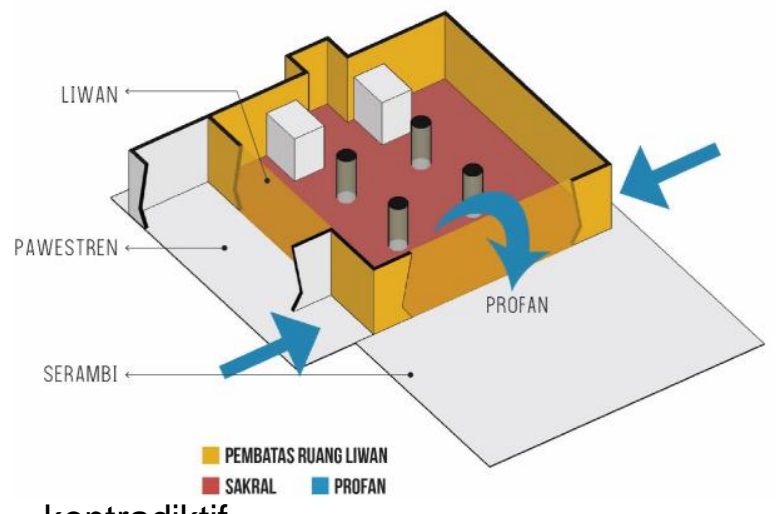

kontradiktif.

Gambar 15. Pembatas Ruang pada Liwan (Sumber: data penulis)

Dinding yang mengelilingi liwan berfungsi untuk memisahkan dan mengeluarkan kegiatan-kegiatan profan ke luar liwan dan dialokasikan ke serambi. Salah satu upaya yang sangat tampak adalah jadwal menutup seluruh akses untuk memasuki liwan setiap jam 20.00 hingga 24.00 setiap harinya. Sekalipun dalil Qur'an Surat AnNisa ayat 43 menunjukkan bahwa masjid boleh dilewati atau sebagai tempat lalulalang oleh orang yang sedang dalam keadaan tidak suci, ta'mir masjid menjaga liwan agar terhindar dari hal-hal yang tidak 
suci.

Selain itu, dinding tersebut mengurangi cahaya matahari yang masuk ke dalam liwan, sehingga liwan cenderung lebih gelap dibandingkan dengan serambi. Bagi sebagian banyak orang, beribadah ditempat yang lebih gelap dapat mendukung kekhusuan ibadah. Contohnya, ketika pintu liwan dibuka kembali pukul 24.00, lampu liwan tidak dinyalakan semua dengan tujuan agar orang-orang yang sedang ber-i'tikaf dapat mencapai kekhusuan yang optimal. Tidak ada dalil yang menganjurkan secara khusus untuk Shalat di tempat yang gelap, sehingga para ulama berpendapat bahwa hukumnya mubah (diperbolehkan).

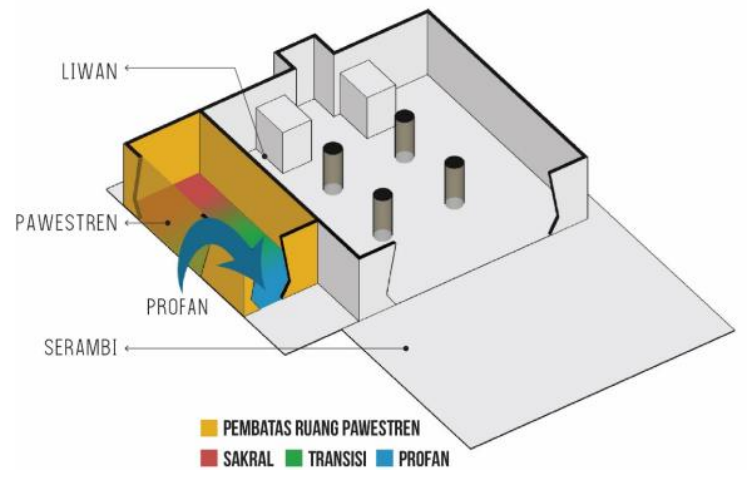

Bagan 16. Pembatas Ruang pada Pawestren (Sumber: data penulis)

Bertolak belakang dengan Pawestren. Dengan memiliki dinding yang masif, pawestren justru mengakomodasi seluruh kegiatan wanita, dari kegiatan suci hingga kegiatan profan. Hal ini terjadi karena dinding tersebut dianggap mampu menghalangi akses masuk bagi pria, walaupun hanya sekadar pandangan atau visual saja, sehingga wanita yang menjaga aurat sesuai syari'at merasa lebih bebas untuk beraktivitas seperti yang ada di serambi, yaitu duduk santai, bercengkrama hingga berbaring. Larangan di pintu masuk pawestren bahwa wanita yang sedang haid dilarang masuk menunjukkan ada upaya ta'mir menjaga pawestren dari hal-hal tidak suci yang dapat mengotori atau mencemarkan kesucian ruang.

Kesucian merupakan syarat utama dalam INERSIA, Vol. XIV No. 1, Mei 2018 setiap ritual ibadah. Kriteria suci dalam Islam berarti tidak terkena najis. Segala sesuatunya dalam Islam berhukum asal suci. Bila ada sesuatu yang diklaim sebagai najis, maka harus ada dalil yang mendasarinya. Kesucian pakaian dan tempat menjadi prioritas pertama yang harus diperhatikan sebelum beribadah.

Ketika menempati liwan maupun pawestren, atau bahkan serambi sebagai tempat shalat, kesucian tempat bisa dipercayakan pada perawatan yang dilakukan oleh ta'mir. Namun bila terjadi pembengkakan jumlah jama'ah sehingga liwan, pawestren dan serambi tidak mampu menampung, mengakibatkan jama'ah akan menggunakan ruang-ruang lain sebagai tempat ibadah. Salah satu contoh kasusnya adalah Shalat Jum'at.

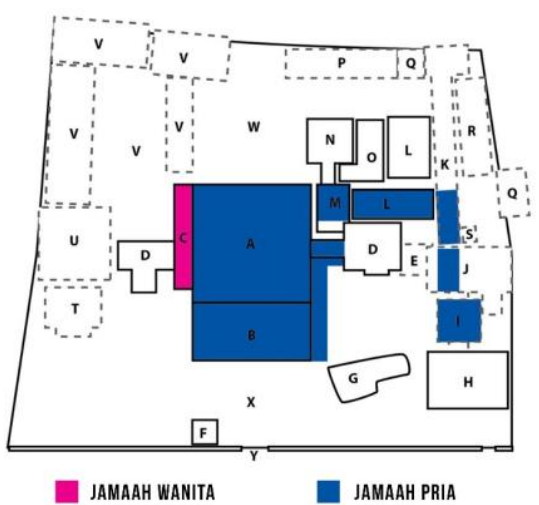

Bagan 17. Penggunaan ruang di Masjid Agung Demak saat Shalat Jumat

(Sumber: data penulis)

Shalat Jum'at di Masjid Agung Demak dihadiri oleh jama'ah pria dan juga wanita, meskipun tetap didominasi oleh jama'ah pria. Jama'ah wanita tetap menempati pawestren. Liwan dan serambi tidak cukup untuk menampung semua jama'ah pria yang hadir, sehingga harus menggunakan ruangan lain. Jama'ah pria yang datang lebih awal akan mendapat tempat di liwan dan serambi, sedangkan bagi yang terlambat akan mendapat tempat di halaman, koridor tempat wudhu, tajuk, paseban, koridor makam, dan juga ruang transit. Mereka yang menempati ruang selain liwan dan serambi membawa sajadah sendiri dan menggelarnya di ruang-ruang tersebut. 


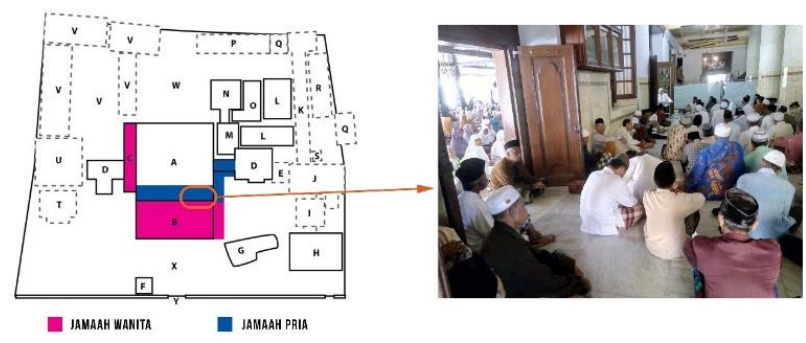

Bagan 18. Penggunaan ruang di Masjid Agung Demak saat Tabligh Akbar

(Sumber: data penulis)

Hal serupa terjadi ketika Masjid Agung Demak mengadakan Tabligh Akbar untuk memperingati Hari Santri pada tanggal 20 Oktober 2017. Sebagai syarat sah dalam setiap ritual ibadah, suci atau bersih dari segala kotoran baik yang terlihat maupun tidak harus diperhatikan sebelum menggunakan tempat terutama di ruangruang profan. Ketika ruang profan harus digunakan sebagai perluasan ruang sakral, baik pengurus maupun jama'ah harus berupaya agar ibadah yang sedang dilakukan memenuhi syarat sah tersebut. Maka ruang profan dapat menjadi layak sebagai tempat beribadah bila dibersihkan, atau dialas dengan tikar atau sajadah.

\section{SIMPULAN}

Berdasarakan kesakralan di Kompleks Agung Demak, ruang yang disakralkan adalah liwan dan pawestren sebagai ruang utama untuk Shalat dan makam sebagai tempat berziarah. Istilah sakral untuk Shalat dan ruang yang digunakan untuk Shalat adalah suci, sesuai dengan dalil AlQur'an dan Hadits yang mengatur tentang syarat sah Shalat. Sedangkan istilah sakral untuk ziarah dan makam-makam adalah keramat, karena kegiatan ziarah yang dilakukan di Masjid Agung Demak tidak didasari oleh dalil, melainkan keyakinan bahwa berziarah di makammakam tersebut dapat mendatangkan berkah. Bila dilihat lebih dalam lagi, pada setiap ruang-ruang di masjid Agung Demak kesakralan terbagi menjadi dua makna, yaitu sakral karena kesucian atau kebersihannya sebagai ruang untuk beribadah dan sakral karena dikeramatkan. Liwan dan Pawestren di
Masjid Agung Demak dianggap dan diperlakukan sebagai ruang suci, walaupun ditemukan adanya kegiatan profan pada pawestren.

Selain sebagai ruang sakral, pawestren juga berfungsi sebagai ruang profan bagi para wanita karena wanita dapat bebas melakukan berbagai hal dengan nyaman. Pawestren didominasi oleh kegiatan profan. Sebagian wanita yang memegang syari'at dalam bertingkah laku tentu menjaga agar auratnya tidak tampak sama sekali oleh sembarang pria. Serambi, menjadi ruang untuk jama'ah berlalulalang dan beristirahat dengan berbagai kegiatan profan, baik saat sampai di kompleks Masjid Agung Demak maupun setelah melaksanakan ibadah.

Faktor-faktor yang mempengaruhi kesakralan ruang adalah pembatas fisik dan kesucian ruang ibadah. Pembatas fisik yang masif di pawestren membuat ruang tersebut suci hanya untuk wanita, tapi didominasi dengan kegiatan profan karena kebebasan wanita beraktivitas di dalamnya tanpa terlihat oleh sembarang pria. Bertolak belakang dengan liwan yang didalamnya sangat didominasi dengan kegiatan sakral (suci) karena dibatasi dinding, dan juga serambi yang menjadi profan karena tidak memiliki batas fisik yang masif. Sedangkan kesucian menjadi syarat sah kegiatan ibadah, sehingga menjadi syarat utama sakral atau tidaknya sebuah tempat. Menjaga kesucian diri, pakaian maupun tempat/ruang merupakan cara menghormati kesakralan ruang. Ruang sakral sangat dijaga kesucian tempatnya. Ketika ruang profan harus berubah fungsi untuk mendukung ruang sakral, maka perlu diperhatikan bagaimana kesucian tempat tersebut dengan berbagai upaya seperti membersihkan tempat atau mengalas tempat ibadah dengan menggunakan tikar atau sajadah.

\section{DAFTAR RUJUKAN}

Ayub, Moh. E. 1996. Manajemen Masjid. Jakarta: Gema Insani.Fabrian.

Dhavamony, Mariasusai. 1995. Fenomenologi Agama. Sleman: PT 
Kanisius. Pranowo, Labdo. 2014.

Malangjudo, et. all. 2015. Pola Sistem Setting Natah di Rumah Tinggal Orang Bali pada Lahan Terbatas di Yogyakarta. Jurnal Arsitektur dan Perencanaan. Edisi April 2015. Jurusan Tekni Arsitektur dan Perencanaan Fakultas Teknik Universitas Gadjah Mada, Yogyakarta.

Marwoto, dkk. 2014. Masjid Agung Demak sebagai Pencitraan Kawasan Kota. Prosiding Temu IImiah IPLBI 2014

Muhammad, Nurdinah. 2013. Memahami Konsep Sakral Dan Profan Dalam Agama-Agama. Jurnal Substantia Vol. 15, No.2, Oktober 2013, hal. 268-280.

Purwanto. 2014. Peranan Keberadaan Masjid Agung Demak Dalam Perkembangan Kehidupan Sosial Ekonomi dan Budaya Masyarakat
Kelurahan Bintor Kecamatan Demak Kabupaten Demak. Jurnal IImiah Pendidikan Sejarah IKIP Veteran Semarang Vol. 02. No.1, Nopember 2014.

Rasdi, Mohamad Tjuddin Haji Mohamad. 1998. Masjid: Pusat lbadat dan Kebudayaan Islam Edisi 3. Jakarta : Pustaka Antara.

Sarwono, S. 2002. Psikologi Lingkungan. Yogyakarta: Gadjah Mada University Press.

Setiawan, Haryadi B. 1995. Arsitektur Lingkungan dan Perilaku. Yogyakarta: Direktorat Jenderal Pendidikan.

Sumalyo, Yulianto. 2006. Arsitektur Masjid dan Monumen Sejarah Muslim Yogyakarta: Gadjah Mada University Press. 